\title{
The 1964 Wellington Study of Beatlemania Revisited
}

\author{
A. J. W. Taylor \\ School of Psychology, Victoria University of Wellington, Wellington, New Zealand \\ Email: tony.taylor@vuw.ac.nz
}

Received 24 July 2014; revised 21 August 2014; accepted 16 September 2014

Copyright (C) 2014 by author and Scientific Research Publishing Inc.

This work is licensed under the Creative Commons Attribution International License (CC BY). http://creativecommons.org/licenses/by/4.0/

(c) (i) Open Access

\begin{abstract}
In June 1964, an Honours class in clinical psychology set out to objectify the major parameters of crowd and audience reaction to the Beatles' during the group's three-day visit to Wellington, New Zealand. Advance publicity had warned of the "mass-hysteria" to be expected at the sight, sound and lyrics of the four lads from Liverpool. Adolescents anticipated their arrival eagerly, while the authorities were disparaging and somewhat fearful of the breakdown in law and order that might occur. The findings were published in Britain in 1966, taken a little further in the United States in1968, and the original published once more in Britain in 1992 by special request to encourage more psychologists to undertake research off campus. When writers from those countries mentioned the study recently near the $5^{\text {th }}$ anniversary of the Beatles' visit, it seemed interesting to review the accretion of similar studies that might have occurred. Sadly, the outcome showed that psychologists had not taken mass-audience research any further. Hence it was thought appropriate to lift the Wellington study from obscurity, in the hope of inspiring the next generation to make amends.
\end{abstract}

\section{Keywords}

Beatlemania

\section{Introduction}

The Beatles began their nine-day tour of New Zealand on $21^{\text {st }}$ June 1964. It was at the end of their Hong Kong/ Australasian tour. Late in 2012 a "look-alike" group named "Bootleg Beatles" revived feelings of either nostalgia or disdain in the elderly by holding concerts in the main centres of the country. Advance publicity of a similar group recently promised to recreate "the magic moments of that incredible 1964 tour" nearer the actual date of the $50^{\text {th }}$ anniversary of the Beatles arrival. 
How incredible was the tour? The group's notable achievements in terms of awards and peak-sale of records had already far surpassed those of any other musical combination (cf. Fulpen, 1982; Burt, 1983). Just a few months earlier when the Beatles appeared on the Ed Sullivan television show in the USA, they reached an audience of 73 millions - more than a third of that country's population at the time. They crested a huge wave of energy that broke barriers of discontent. Like the 'hippies', they appealed for love to reign over discord.

As expressed succinctly in the caption beneath the picture of the Beatles in The Timechart History of the World (Anon, 2011: p. 16), "their rock"n roll music played a leading part in a popular cultural revolution around the world in the 1960s'.

But the revolution the Beatles helped to bring to a head had more components than the cultural. The aftermath of World War 2 had yet to fulfill the promise of stability and prosperity. Colonial self-determination was rising. The legitimacy of wars in Korea and Vietnam was seriously in question. The threat of nuclear war with the Soviet Union loomed large, as did the fearful prospect of a "nuclear-winter" from industrial accidents involving nuclear power. Animosity rumbled from endemic racism, social injustice, sexual inequality, dissident theology, the power of the military-industrial complex, and the conventional containment of the young (cf. Toffler, 1970). The volatile combination made the establishment more determined than ever to preserve the status quo against the demands of any unruly and strategically naïve Beatle fans.

Not all of such contentious issues were evident in New Zealand when the Beatles came. In many respects the country's geographical position in the far South Pacific had cocooned it from the rest of the world. To some extent a radio network and a limited evening television service punctured the isolation. The country relied heavily on shipping for transport, with only a rudimentary international air-link with Australia. Merchants traded mostly with Britain, because of the country's heritage and constitutional ties with the British Commonwealth. Ships' crews brought the latest recorded music with which to entertain dockside locals. Saturdays were set aside for playing sport, and Sundays for attending church. The sale of alcohol was severely restricted, with bars closing at six every evening except Sundays when they were closed all-day. The consumption of alcohol was prohibited in dancehalls and restaurants. Shops stayed open late on Friday nights and closed at weekends. Cinemas played the British National Anthem at the close of every performance, and colleges demonstrated their patriotism with Army Cadet Units. Racial problems rumbled beneath the surface, largely because parliament had still to honour its obligations to indigenous Maori under the country's founding 1840 Treaty of Waitangi.

In this general ambience, the 1964 Wellington study found that younger adolescent females were most affected by the Beatle music. But they were clinically untroubled, less mature, and no more troublesome socially than any other group involved (Taylor, 1966 \& 1968). In 1992 the special edition of Clinical Psychology Form reprinted the original Taylor 1966 article in the hope of inspiring more psychologists to follow with similar studies involving the community.

Whatever response psychological researchers might have made subsequently to involve the community in other topics, they ignored mass-audience reactions to music. On $8^{\text {th }}$ March 2014 the staff of Science Newsletter reported that "there has not been enough serious study on mass adolescent reactions to explain the impact of these four mop-headed British youths... (and said that) psychologists were as puzzled as parents over the explosive effect the Beatles were having on American teen-agers" (cf.

https://www.sciencenews.org/article/beatles-reaction-puzzles-even-psychologists-accessed 18 June 2014). It was the very same complaint their predecessors had made 50 years earlier. Shortly afterwards, the current editors of both The British Journal of Clinical Psychology and The British Journal of Social Psychology expressed no interest in promoting the topic (personal communication via the British Psychological Society, 26 June 2014).

Instead, psychologists left media scholars and journalists to express their opinions without the support of empirical research. Among the more moderate of them, Joli Jensen (1992) described "fandom" with discernment as:

"a psychological symptom of presumed social dysfunction that allows others to regard them as disreputable, and dangerous. In press coverage the dangers of violence, drink, drugs, sexual and racial mingling are connected to music popular with young people... the fan is seen as being irrational, out of control, and prey to a number of external forces".

More recently, Dorian Lynskey (2013) covered a range of media reports on the behavior of Beatle fans (cf. http://www.theguardian.com/music/2013/sep/29/beatlemania-screamers-fandom-teenagers-hysteria -accessed 18 June 2014). For the record, he included Paul Johnson's fulminations of 28th February 1964 that described "this apotheosis of inanity... (with Beatles fans forming) a bottomless chasm of vacuity... who scream themselves 
into hysteria, whose vacant faces flicker over the TV screen, are the least fortunate of their generation, the dull, the idle, the failures". Overall he acknowledged the group's initiatives that changed contemporary roll and roll music and aroused the audience. Michael Tomasky wrote of the mass-reaction in a similar vein, but at least he did mention the New Zealand study, if only to trivialize it (cf.

http://www.thedailybeast.com/articles/2014/01/30/you-ve-got-to-be-kidding-why-adults-dismissed-the-beatles-i n-1964.html-accessed 20 June 2014). For their part, aficionados Greg Armstrong and Andy Neill intend to do better (private communication 19 November 2013).

However, the independent replication of a study is the sine qua non in the acquisition of knowledge. It validates the methodology, methods and suitability of the instruments that were used, and the findings. In the present case, because the peak of the Beatles era has passed, the replication would need to be conducted with fans of one of the major musical groups that followed.

In the meantime the personal observations and insights of Cynthia Lennon (1978) and of Carol Bedford (1984) suffice for what might be termed "approximate validation”, because independently they both happen to add substance to the findings of the 1964 Wellington study. Cynthia Lennon (1978) was John's first wife. She understood that the fans contributed substantially to the Beatles’ success, but blamed them for destroying her marriage. She said that once the music began on stage:

"the mass of humanity overheated, screaming their appreciation... swaying, clapping, (their) heaving bodies caught up in the indescribable ecstasy of the explosion of their pent-up emotions (p. 67)... the Beatles' would grab their audiences musically, emotionally, and sexually... Hysteria and Beatlemania was growing out of all proportion... I was on the fringe of the madness (p. 73)... when fans found out (where we lived) it became unbearable. We were trapped like caged animals. Girls of every shape, size, colour, creed and nationality would sit on the steps in all weathers clutching autograph books in their hands. The screaming hysteria would deafen us, hands would grab, stretch out and touch, pull at our clothes (p. 96)... fanatical girls... after having waited all day would leap onto John with all the ferocity and strength of a bunch of wild animals, claws at the ready" (p. 97). (Soon the Beatles became) "bored by the monotony of concerts that reduced them to performing puppets in the face of thousands of hysterical fans. They couldn't even hear themselves play, let alone gain artistic satisfaction from music that trapped them creatively and physically into repetitive roles as the four Mop-Tops playing again and again their original hit songs” (p. 129).

Carol Bedford (1984) was a Beatle fan whose attachment was extreme but restrained in its expression, except when she broke into Paul McCartney's home with some other devotees on the spur of the moment and stole memorabilia (pp. 80-110). Her infatuation began in 1963 when she was a teen-ager.and it lasted for about nine years. The Beatles were touring the USA at the time, and after attending two of their concerts she followed them to London. There she joined the inner circle of self-named "Apple Scruffs" that camped in doorways near the Apple recording studio, winter and summer, hoping to catch a brief glimpse of their particular idol. A smile, a personal note, or a word of encouragement was sufficient to sustain their nightly vigils. Tidbits of information provided by friendly doorkeepers about the Beatles' future movements, were a bonus. The devotees tolerated rivalry for the same person with minimal rancor, and shared accounts of their victories via a quarterly journal. George Harrison was her idol, and he remained so until she reached the conclusion that:

“You can worship someone as an idol so long as you don't know them... In my adolescence I listened to the Beatles music and thought they had all the answers. They could solve my problems. Later, as George and I would talk, I realized he was as messed up as I was (if not more so due to his experience with the Beatles). This was a crushing disappointment... Also, as I got to know him, I realized I was one of his nightmares. I, who professed to love and care for him, was one of his daily pressures, Therefore to really care for him, I was forced to stay away from him” (Bedford, 1981, pp. 139-140).

Yet she had no regrets for the years she had spent in limbo, and said she would repeat them should the opportunity come again. She gained a university degree and joined the recording industry ${ }^{1}$.

Thus, despite the continuing silence of colleagues in academia, it seemed appropriate to reconsider the essentials of the 1964 study. Before doing so, attention will be given to 1) the historical record of mania associated with music, 2) the psychiatric affirmation of hysteria as maladaptive behaviour of individuals in groups as well as singly, 3) the developmental stages of the Beatles as a musical group, and 4) the most recent publications on

${ }^{1}$ Further information about the "scruffs" can be obtained from http://www.meetthebeatlesforreal.com/2009/12/apple-scruffs.html accessed 20 July 2014. 
related phenomena.

1) The historical record of mania associated with music

The term Beatlemania refers to the widespread disruption created by the four "cheerful wisecracking moptops" from Liverpool ${ }^{2}$. In some respects it could be thought akin to the dancing mania that spread in Europe during the Middle Ages when women danced "with wild abandon". That activity had been ascribed variously to demonic possession, eating bread tainted with ergot mold, the after-effects of plagues, and being overwhelmed by widespread natural disasters. Anthropologists reported that dancing by both sexes also featured in the religious/cultural rituals of primitive tribes (cf. Hecker, 1844; Winnington-Ingram, 1948; Backman, 1952).

The radical Swiss/German itinerant philosopher/physician/polymath Paracelsus (1493-1541) took a more benign view. He described dancing manias the state in which "the blood is set in commotion in consequence of an alteration in the vital spirits, whereby fits of intoxicating joy and the propensity to dance are occasioned” (cf. http://www.public-domain-content.com/books/black_death_dancing_mania/d15.shtml_accessed 20 June 2014). Sadly the "joy" became a compulsion unto death for many of the dancers.

Subsequent reports of mass-reactions to music on other occasions were extreme but not alarming. An observer writing in the 1840s about the sensational playing by pianist Franz Liszt, described "how convulsively his mere appearance affected them! How boisterous was the applause (that) rang to meet him!... What acclaim it was! A veritable insanity, one unheard of in the annals of furor" - cf.

http://en.Wikipedia.org/wiki/Lisztomania_(phenomenon)_accessed 19/6/2014. In the late 1940s and early 1950s crooner Frank Sinatra and rock-star Elvis Pressley evoked similar reactions.

2) Psychiatric affirmation of hysteria as maladaptive behavior of individuals in groups

William Sargent (1957, pp. 92-93) — a psychiatrist not known for deviating from the biological model to explain behavior-acknowledged the power of music in producing hysteria in full-membership rituals of primitive tribes. His contemporaries Wilhelm Mayer-Gross, Elliott Slater \& Martin Roth (1960: pp. 131-146), like psychoneurologogists Jean-Martin Charcot and Sigmund Freud some 70 years earlier, held that cognitive, behavioural and social deficits created the clinical condition ${ }^{3}$.

In an extensive review of clinical hysteria, psychiatrist Simon Wessely (1987) identified two major groups, neither of which could be explained by physical disease. He named them "mass-anxiety hysteria" and "massmotor hysteria" respectively. Both affected people "who would not normally behave in this fashion”. He excluded people with symptoms that were "deliberately provoked in groups gathered explicitly for the purpose, (and the) collective manifestations used to obtain a state of satisfaction unavailable singly, such as fads, crazes and riots. Finally, (he insisted that) the link between the participants must not be coincidental”. In no case did music feature as a research variable specifically as a research variable in the manifestation.

Similarly, the compilers of medical dictionaries expanded the category of hysteria from a condition affecting individuals "characterized by excitement or anxiety, irrational behavior or beliefs, or inexplicable symptoms of illness”, to include the same symptoms affecting groups of people. Specifically, they described mass hysteria as a "socially contagious frenzy of irrational behavior" in reaction to an event (cf.

http://dictionary.reference.com/browse/mass+hysteria-accessed 29 June 2014). However, again the list of such events included none that were induced by music.

3) Developmental stages of the Beatles as a musical group

At the time the 1964 Wellington study was undertaken, the Beatles were in what might now be regarded as the second phase of five that made up their 10-year history as a group ${ }^{4}$, i.e.:

Phase 1: 1959 to 1961 - their music was in the mainstream of Rock and Roll, and they performed in the less salubrious parts of Liverpool near their homes. They pinned their hopes on earning a living as musicians, and developed their talents through short-term contracts $n$ the raucous fleshpots of Hamburg.

Phase 2: 1962 to 1964-Brian Epstein became the group’s manager. He tidied their personal appearance and stage presentation. George Martin became their musical adviser, and under his guidance Ringo Starr became the drummer to provide the particular beat that produced the fervent audience response. Initially the group composed their own melodies and wrote lyrics about the agonies and ecstasies common to adolescents in the cycle of love. They spread their wings to give concerts in Denmark, France, the USA, Asia and Australasia.

\footnotetext{
${ }^{2}$ Andy Lothian, a former Scottish music promoter, is credited with having coined the term while speaking to a reporter after the Beatles' Mini-Tour of Scotland, on October 7, 1963 (accessed 3 July 2014 from www.en.wikipedia.org/wike/Beatlemania).

${ }^{3}$ The manuals of the World Health Organisation and the American Psychiatric Association had yet to become authoritative classificatory guides for mental diseases and disorders.

${ }^{4} \mathrm{Cf}$. Tim Hill (2012) for a comprehensive pictorial coverage of the entire life-cycle of the Beatles as a musical group.
} 
Phase 3: 1965 to 1967—the Beatles rode an unprecedented commercial and professional tsunami. They accepted honours from the Queen-to the dismay of a few former recipients. Tumultuous concert receptions dominated their lives and cramped their creativity. For professional reasons as well as the need for personal security, they confined their talents to making films and records.

Phase 4: 1968-under the influence of psychedelic drugs and Indian mysticism, the Beatles sought inner sensations and purity. Their lyrics became existential and their musical arrangements experimental. Brian Epstein's death prompted the group to realign its top-heavy managerial structure and make its business empire commensurate with their new objectives.

Phase 5: 1969 onwards - The commercialism that fanned the Beatles flame destroyed their musical creativity. The group lost its coherence, and the performers went their separate ways. John Lennon linked with Yoko Ono on the fringe of “flower-power" protest and student revolution in the United States. (In December 1980 a deranged gunman/fan killed him for making off-hand remarks about Jesus Christ).George Harrison, who had also been attacked by a deranged fan, became an exponent of a 12 stringed Sitar. He died of throat cancer in 1981. Paul McCartney held centre-stage by mounting new musical productions that continue to this day. In 1997 he was knighted for services to music, and in 2012 he played a prominent part in the concert to mark her Majesty's Diamond Jubilee. Ringo Starr kept out of the spotlight, but he continued to make the occasional concert appearance.

4) Recent reports of related phenomena

Sociologists Robert Bartholomew \& Erich Gooch (2000) updated the list events of mass-hysteria in which cultural, industrial, religious, and social factors played a part. Psychiatrist John Waller (2009a \& 2009b) brought dancing mania of the Middle Ages to the fore. Psychologists Reddish, Fischer, \& Bulbulla (2013) published an article on the significance of shared synchrony, intentionality and cooperation in dance partnerships ${ }^{5}$. Finally, in an impressive study of the kind that this author has in mind, psycho-physiologists Trimble, Mathias and Owensp reported the primitive autonomic reactions to a dramatic passage in Verdi's Simon Bocconegra (cf.

http://www.youtube.com/watch?v=EVN4dShaZWk-accessed 1 August 2014). They found that the segment induced similar responses in an opera-lover and a novice: it affected their heart rate, blood pressure, breathing rate and sweat gland activity.

\section{The 1964 Welligton Study Restated}

\subsection{Aim/Methodology}

The aim was to observe the behavior of fans to the Beatles and their music, and to identify the major psychological factors involved. The results were to depend on differences found between a large group of the keenest fans and another of the resisters drawn from the same population

\subsection{Method}

The study was conducted in the following five stages:

Stage 1. Ten post-graduate students mingled among crowds at the airport and outside the Beatles' hotel to identify individuals displaying outward signs either of exuberance and dissociative states or of indifference or disdain. The aim was to involve 400 participants, and hand them suitably phrased invitations to attend psychological testing sessions a week later at the university.

Appropriate precautions were taken to ensure that the authorities would observe the bona fides of the students, were any inadvertently to become embroiled in some kind of melee.

Stage 2. The study used standard tests of clinical hysteria, neuroticism, and personality to differentiate the keenest of Beatle fans from their counterparts. The tests consisted of the Hysteria scale of the Minnesota Multiphasic Personality Inventory (MMPI), the Maudsley Scale of Neuroticism (MPI), Raymond Cattell's 16 Personality Test (16PF), and, to be sure that enough respondents in the sample fell at the extremes, a hastily constructed 10-item self-scored Test of Beatlemania, since renamed the Beatles-Fan Scale (Appendix) ${ }^{6}$. Finally a brief personal questionnaire was added to elicit the age of respondents, discover whether they lived at home or away, and had ben in trouble with the law.

\footnotetext{
${ }^{5}$ Heavy metal guitarist/Managing-Editor of The Psychologist Jon Sutton (2013) is mentioned, although he made just a personal plea to his colleagues in psychology for help in honing his musical skills.

${ }^{6}$ Although the Beatle Fan measure proved to have face validity, there was insufficient time to conduct the customary item analysis before it was used.
} 
Clinical observations were made of participants before, during, and after testing sessions, and attention was paid to reports of any untoward behavior they might have displayed to the Beatles music.

Stage 3. John Lennon was interviewed at a press conference to discover the part the group played in producing the effects. The New Zealand Broadcasting Commission provided the equipment and a technician to record the first interview in return for an account to be given later on the radio.

Stage 4. Observations were made of the music and lyrics, the sound and lighting effects, the ambience and audience response at two Beatle concerts.

Stage 5. An alternative plan to access participants was made when the crowds proved too packed for the students to move about and recruit a sufficient number of participants.

By that time, having estimated the age range of those that seemed most affected, access was gained to classes of adolescents in which teachers identified pupils displayed a range of interest in the Beatles . A sample of slightly older students was also accessed at a teachers college, to check the significance of age of respondents with the condition.

Four "measures" were used to confirm the teachers' judgments. The first came from observing the reactions of subjects to the playing of Beatle music on a tape recorder as they entered the test room. The second from the banter that arose between rival factions. The third from the variety of their responses to the Beatle-Fan Scale, and the fourth from the acceptance or rejection of cyclostyled copies of Beatle signatures as they left.

Stage 6. The psychometric tests were scored by hand, and the data processed by using a desktop electrically operated calculator - the university had yet to install its first computer-a huge Elliot 404. Statistical comparisons were made between different groups of respondents according to their gender, age, deviance, and their scores on the Beatle Fan Scale.

\subsection{Results}

1) Three hundred and forty-six participants completed the assembly of psychometric tests. They were separated into groups according to their scores on the now renamed Beatle-Fan Scale. The 50 with the highest scores were compared with a similar number with the lowest, and a middle clump of 122 was compared the group on each side. Then the groups were subdivided by gender for further inter-group comparisons (cf. Table 1 \& Table 2).

2) From observations, none in any group showed behavioural symptoms of disturbance, and the teachers reported none to have been in need of clinical referral.

3) Younger adolescent females were the pupils most affected. Their 16 PF scores were significantly higher on factors of cyclothymic, assertiveness, activity levels, tendency to worry, tension and excitability than those of their counterparts in the group of resisters. Their Maudsley Neuroticism scores showed them also to be more inclined towards emotional instability. They differed significantly from the moderate group of females only withhigher scores on surgency.

The females in the moderate group also differed significantly from the resisters on higher $16 \mathrm{PF}$ scores on surgency, excitability, and a tendency towards emotional instability shown on the Maudsley scale.

In turn, the males in the middle group were significantly more inclined towards emotional instability than the male-resisters.

4) The Social Background Schedule disclosed that the great majority of respondents in all groups had not been in trouble with the police, and they were living at home (Table 3).

5) John Lennon was interviewed twice. The first interview occurred during the scrum of a press conference at their hotel soon after their arrival, and the second two days later because of a suspected recording failure during the first. By that time the interviewer was more focused in his questioning, because he had the benefit of attending one of their concerts. At both interviews John Lennon confirmed the group's use of a particular beat to arouse the audience, but he could not say whether a technician might have primed the audience ${ }^{8}$. He said that the group created the particular audience-reaction initially in Hamburg the year before, when Ringo Starr replaced Pete Best as the drummer to provide a distinctive beat that resonated with the late-adolescents there. He commented that their lyrics featured the simple themes of "falling in love, falling out of love, and falling in love again". He thought the response greater in Germany than elsewhere, because heavier parental hands controlled their offspring.

\footnotetext{
${ }^{7}$ None had been considered in need of clinical referral. There was also no bias towards the better educated, because school attendance was compulsory until pupils were over 16 years of age.

${ }^{8}$ Incidentally, John Lennon complained that the music at the first concert in Wellington was not loud enough because the sound system was faulty.
} 
Table 1. Psychometric results of females.

\begin{tabular}{ccccc}
\hline Middle & Low or resisters & High to low d.f. 78 & High to middle d.f. 97 & Middle to low d.f. 97 \\
\hline 59 & 40 & & & $5.1^{* * *}$ \\
9.75 & 2.10 & $16.14^{* * *}$ & $8.45^{* * * *}$ & $3.5^{* * *}$ \\
16.12 & 18.30 & $3.006^{* *}$ & 0.3185 & 2.002 \\
10.15 & 9.125 & $2.267^{*}$ & 0.354 & 0.928 \\
8.37 & 7.15 & 1.084 & 1.024 & 0.938 \\
15.97 & 16.60 & 1.459 & 0.358 & 1.045 \\
13.10 & 12.225 & $2.508^{*}$ & 1.224 & $3.492^{* * *}$ \\
16.14 & 13.45 & $6.059^{* * *}$ & $2.489^{*}$ & 0.30 \\
11.66 & 11.475 & 0.285 & 0.024 & 1.92 \\
12.20 & 10.25 & 1.844 & 0.122 & 1.784 \\
13.00 & 12.05 & 0.977 & 0.938 & 0.48 \\
8.36 & 8.00 & 1.395 & 1.036 & 0.953 \\
11.63 & 10.875 & 0.105 & 1.14 & 0.619 \\
9.66 & 9.025 & 0.484 & 0.711 & 1.51 \\
11.53 & 10.55 & $2.875^{* *}$ & 1.437 & 1.31 \\
10.29 & 9.50 & 1.337 & 0.02 & 1.123 \\
9.73 & 10.375 & 1.735 & 0.642 & 1.800 \\
9.17 & 10.10 & 1.817 & 0.255 & $2.700^{* *}$ \\
13.32 & 11.025 & $3.739^{* * *}$ & 1.158 & $2.616^{* *}$ \\
11.42 & 8.45 & $3.391^{* * *}$ & 0.751 & 0.371 \\
20.22 & 19.875 & 1.232 & 0.877 & \\
\hline
\end{tabular}

${ }^{* * *} p<0.001,{ }^{* *} p<0.01,{ }^{*} p<0.05$.

Table 2. Psychometric results of males.

\begin{tabular}{|c|c|c|c|c|}
\hline Middle & Low or resisters & High to low d.f. 18 & High to middle d.f. 71 & Middle to low d.f. 71 \\
\hline 63 & 10 & & & \\
\hline 9.97 & 0.09 & $9.831^{* * *}$ & $8.371^{* * *}$ & $13.52^{* * *}$ \\
\hline 16.50 & 16.40 & 1.077 & 1.674 & 0.220 \\
\hline 8.24 & 8.10 & 0.212 & 0.398 & 0.136 \\
\hline 7.72 & 6.70 & 0.959 & 0.386 & 1.482 \\
\hline 17.31 & 17.10 & 0.41 & 0.428 & 0.137 \\
\hline 14.63 & 14.50 & 1.557 & 1.842 & 0.095 \\
\hline 15.59 & 14.20 & 1.207 & 0.900 & 0.931 \\
\hline 10.75 & 10.20 & 0.262 & 0.645 & 0.854 \\
\hline 11.32 & 10.50 & 0.839 & 0.821 & 0.408 \\
\hline 9.67 & 8.50 & 1.192 & 1.060 & 0.724 \\
\hline 9.78 & 9.10 & 0.225 & 0.893 & 0.716 \\
\hline 10.94 & 10.10 & 0.569 & 0.149 & 0.556 \\
\hline 11.04 & 11.70 & 0.729 & 0.076 & 1.158 \\
\hline 11.53 & 10.70 & 0.569 & 1.545 & 0.531 \\
\hline 11.77 & 11.10 & 1.882 & 1.839 & 0.911 \\
\hline 10.50 & 12.60 & 1.730 & 0.988 & 1.341 \\
\hline 8.96 & 9.90 & 0.529 & 0.129 & 0.812 \\
\hline 13.44 & 11.90 & 0.249 & 0.635 & 0.966 \\
\hline 10.51 & 5.90 & 0.449 & 1.698 & $3.487^{* * *}$ \\
\hline 18.28 & 18.60 & 0.041 & 0.263 & 0.220 \\
\hline
\end{tabular}

${ }^{* * *} p<0.001$. 
Table 3. Social history schedule.

\begin{tabular}{ccc}
\hline & In trouble with police & Living away from home \\
\hline High & 1 & 7 \\
Females (139) & 1 & 13 \\
Middle & $=$ & 18 \\
Low & 1 & 1 \\
High & & \\
Males (63) & 1 & 7 \\
Middle & - & $=$ \\
Low & & \\
\hline
\end{tabular}

6) Each performance lasted just under two and a half hours, and produced much the same response from their audience. The programme involved a succession of two bands playing non-stop for two hours until the appearance of the Beatles for the last 30 minutes or so. Each band changed the tempo and volume of their music, at the peak of which they encouraged the audience to stomp, clap and shout. The front men on stage wore colourful clothing that reflected beams of light as they cavorted about to arouse the audience to fever pitch. When finally the Beatles appeared, their music could not be heard over the din. Pandemonium broke out. Girls screamed, and a few males tried to break through the cordon of police to climb onto the stage. The Beatles carried on regardless to complete their stint. Order was quickly restored when the house lights were turned on and convention obliged the audience to stand to the sonorous beat of the National Anthem. Uniformed police and security staff made their presence felt as the exhausted fans made their way out of the Town Hall.

\subsection{Discussion}

The clinical, observational and psychometric evidence was consistent in showing no psychopathology in the keenest Beatle fans or in any other group. But the younger females gave indications of developmental immaturity.

The majority of both sexes admitted to having been aroused by advance publicity, the uniqueness of the occasion, the exhortations of preliminary performers, and the triumphant appearance of their idols.

The findings supported the observations of psychiatrist David Ausubel (1954, p. 50) that girls show more emotional instability than boys, and reassuringly that the condition is mostly a transient reaction to various developmental strains. None-the-less, questions arose as to whether a group of female musicians might evoke comparable reactions in young males to their music as the Beatles did in young females.

Attention turned to the beat, because it opened the route to stardom for the Beatles ${ }^{9}$. Salk (1962) had shown the reduction in beat frequency to calm fractious infants, and many others had shown the effect of the converse to arouse them. Here the stentorian beat at the Nuremberg rallies comes to mind (cf.

http://www.britannica.com/EBchecked/topic/422665/Nurnberg-Rally_accessed 19July 2014). The same applies to the unlawful use of music to disturb the waking and sleep patterns of detainees held for interrogation (cf. http://en.wikipedia.org/wiki/Music_in_psychological_operations_accessed 22 July2014). However, for centuries music has also been used as a healing force. Today professional exponents practice their skills with a wide variety of patients_-http://en.wikipedia.org/wiki/Music_therapy_accessed 20 July 2014.

Jenny McLeod of the Music Department at Victoria University agreed that the beat frequencies of the same tunes on records as in the concerts were extreme. She found they varied from varied from 57 to 200 per minute. As for the volume, Journalist Karl du Fresne reported recently that a technician had recorded the height as being 109 decibels at a Wellington concert (DominionPost Weekend Magazine, 12 June 2014).

Musicologist Brian Davis (1965) of the Sydney Conservatorium of Music dwelt on the musical structure and lyrics the Beatles presented. He noted that the group made extensive use of modal progressions and archaic scales, and that it arranged the words in classical rhythms. Aldridge (1969: p. 11) considered their music to have “developed into a fascinating social history of our generation and its culture”. He described their lyrics as “a tremendous springboard to the imagination”, and was inspired to produce an impressive book of 45 paintings from fellow artists to illustrate the theme. Then Albert Goldman (1988) provided a credible analysis of the relationship between many of John Lennon's compositions and his far from straightforward emotional and social life.

\footnotetext{
${ }^{9}$ Were the beat proved to be so significant in producing extreme behavior, it could no longer be said to differentiate the music of EuroAmerican from that of non-literate societies (cf. Herscovitz, 1948: pp. 435-439).
} 


\subsection{Conclusion}

The study confirmed the comments and opinions of the less vituperative observers that the keenest of Beatle fans were mostly teenage girls who expressed their adulation in an excessive manner. Their unrestrained display was found to be of developmental but not clinical significance.

Rudimentary attention was paid to the psychophysiological effects of the particular beat and the immediate circumstances in which it was produced.

Typical intergenerational tensions combined with cultural and social issues were thought to set the climate for the audience response.

The study was without precedent, and to date it remains so, despite the opportunity for replication that the mass-reaction to similar pop-groups had provided since the demise of the Beatles.

\section{References}

Aldridge, E. (1969). The Beatles Illustrated Lyrics. London: St. Giles House.

Anon (2011). The Timechart History of the World (4th ed.). Chippenham: Third Millenium Press.

Armstrong, G., \& Neill, A. Half a World Away: The Beatles’ Australasian Tour.

Backman, E. L. (1952). Religious Dances in the Christian Church and Popular Medicine. London: Allen \& Unwin.

Bartholemew, R. E., \& Goode, E. (2000). Mass Delusions and Hysterias: Highlightsfrom the Past Millennium. Skeptical Inquirer, 24.

Bedford, C. (1984). Waiting for the Beatles: An Apple Scruff's Story. Poole: Blanford.

Burt, R., Ed. (1983). The Beatles: The Fab Four Who Dominated Music for a Decade. London: Phoebus/Octopus.

Fulpen, H. V. (1982). The Beatles: An Illustrated Diary. New York: Perigee.

Goldman, A. (1988). The Lives of John Lennon. London: Bantam.

Hecker, J. F. C. (1844). The Epidemics of the Middle Ages. London: Woodfall \& Son.

Herscovitz, M. J. (1948). Man \& His Works: The Science of Cultural Anthropology. New York: Kopf.

Hill, T. (2012). The Beatles: Then There Was Music. Croxley Green: Transatlantic Press.

Jensen, J. (1992). Fandom as Pathology: The Consequences of Characterization. In L. Lewis (Ed.), The Adoring Audience: Fan Culture and Popular Media (pp. 9-26). London: Routledge.

http://books.google.co.nz/books?hl=en\&lr=\&id=uBACZl2rNT8C\&oi=fnd\&pg=PA9\&dq=Fandom+as+pathology\&ots=iv KWly-MVp\&sig

Lennon, C. (1978). A Twist of Lennon. London: Allen.

Mayer-Gross, W., Slater, E., \& Roth, M. (1960). Clinical Psychiatry (2nd ed.). London: Cassells.

Reddish, P., Fischer, R., \& Bulbull, J. (2013). Let’s Dance Together: Synchrony, Shared Intentionality and Cooperation. PLoS ONE, 8, e71182. http://dx.doi.org/10.1371/journal.pone.0071182

Salk, L. (1962). Division of Psychology: Mothers' Heartbeat as an Imprinting Stimulus. Transactions of the New York Academy of Science, 24, 753-763. http://dx.doi.org/10.1111/j.2164-0947.1962.tb01441.x

Sutton, J. (2014). For Those Psychologists About to Rock... The Psychologist, 27, 320.

Taylor, A. J. W. (1966). Beatlemania: A Study in Adolescent Enthusiasm. British Journal of Social \& Clinical Psychology, 5, 81-88. http://dx.doi.org/10.1111/j.2044-8260.1966.tb00958.x

Taylor, A. J. W. (1968). Beatlemaia: The Adulation and Exuberance of Some Adolescents. In M. Truzzi (Ed.), Sociology and Everyday Life (pp. 161-170). Englewood Cliffs, NJ: Prentice Hall.

Toffler, A. (1970). Future Shock. London: Bodley Head.

Waller, J. (2009a). A Forgotten Plague: Making Sense of Dancing Mania. The Lancet, 373, 624-625. http://dx.doi.org/10.1016/S0140-6736(09)60386-X

Waller, J. (2009b). Looking Back: Dancing Plagues and Mass Hysteria. The Psychologist, 22, 643-647.

Weiner, J. (1991). Come Together: John Lennon in His Time. Champaign, IL: University of Illinois Press.

Winnington-Ingram, R. P. (1948). Euripides \& Dionysius. Cambridge: Cambridge University Press. 


\section{Appendix. The Beatles-Fan Scale with Scores and Categories}

Item 1: Did you go to the airport or Town Centre to greet the Beatles?

Score 2 for Yes

Item 2: Were you waiting at their hotel?

Score 2 for Yes

Item 3: For how long have you been interested in the Beatles?

Score 1 for six months: 2 for 12 months,

Score 3 for 18 months, and 4 for 24 months or more

Item 4: How many of their songs do you know?

a) the tunes-Score 1 for zero to 7 : Score 2 for 7 or more

b) the words-Score 1 for zero to 7 : Score 2 for 7 or more

Item 5: Which particular Beatle do you admire most?

Score 2 for each

Item 6: Have you had any previous "pin-ups”?

Score 2 for yes

Item 7: Who were they?

Item 8: If you had got up on the stage, what would you have done?

Score 1 for "shaken hands": 2 for "spoken to them"

Score 3 for "kissed them", and 4 for "hugged them"

Item 9: How did you feel about the Beatles?

Score 1 for "curious": 2 for "interested"

Score 3 for "excited”, and 4 for "wonderful”

Item 10: How different are they from any other group you have known?

Item 1l: Did you mind standing up to dance or scream in the Town Hall?

Score 1 for "No, because everyone was doing it"

Score 2 for "Where else could you scream?"

Score 3 for "It was the only thing to do"

Score 4 for "I could not help doing it"

\section{TOTAL YOUR SCORE AND READ THE APPROPRIATE PARAGRAPH ON THE PAGE BELOW}

SCORE 0 - 5: You resist the Beatle music, their advertising and their appeal. You are inclined to be disdainful of keen Beatle fans: you set yourself apart

SCORE 8 - 12: You are moderately interested in the Beatles, but your interest is likely to yield once another group comes along. Like most other people you are affected by the group pressure to see, buy and applaud to a certain degree

SCORE 16+: You are really with it. The Beatles have captured your imagination, and you are taken by the beat. No doubt you are growing long hair as a boy, and you are wearing boots and a leather cap if you are a girl. Probably the walls of your room are plastered with autographed pictures of the Beatles in colour. 
Scientific Research Publishing (SCIRP) is one of the largest Open Access journal publishers. It is currently publishing more than 200 open access, online, peer-reviewed journals covering a wide range of academic disciplines. SCIRP serves the worldwide academic communities and contributes to the progress and application of science with its publication.

Other selected journals from SCIRP are listed as below. Submit your manuscript to us via either submit@scirp.org or Online Submission Portal.
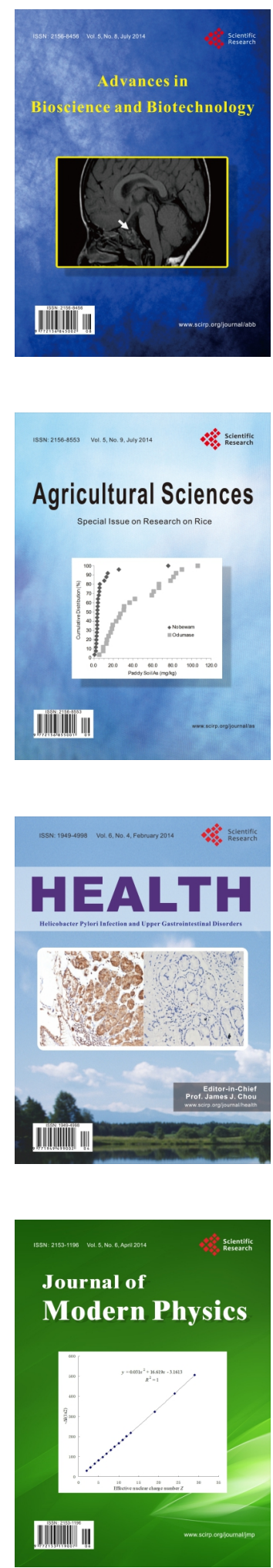
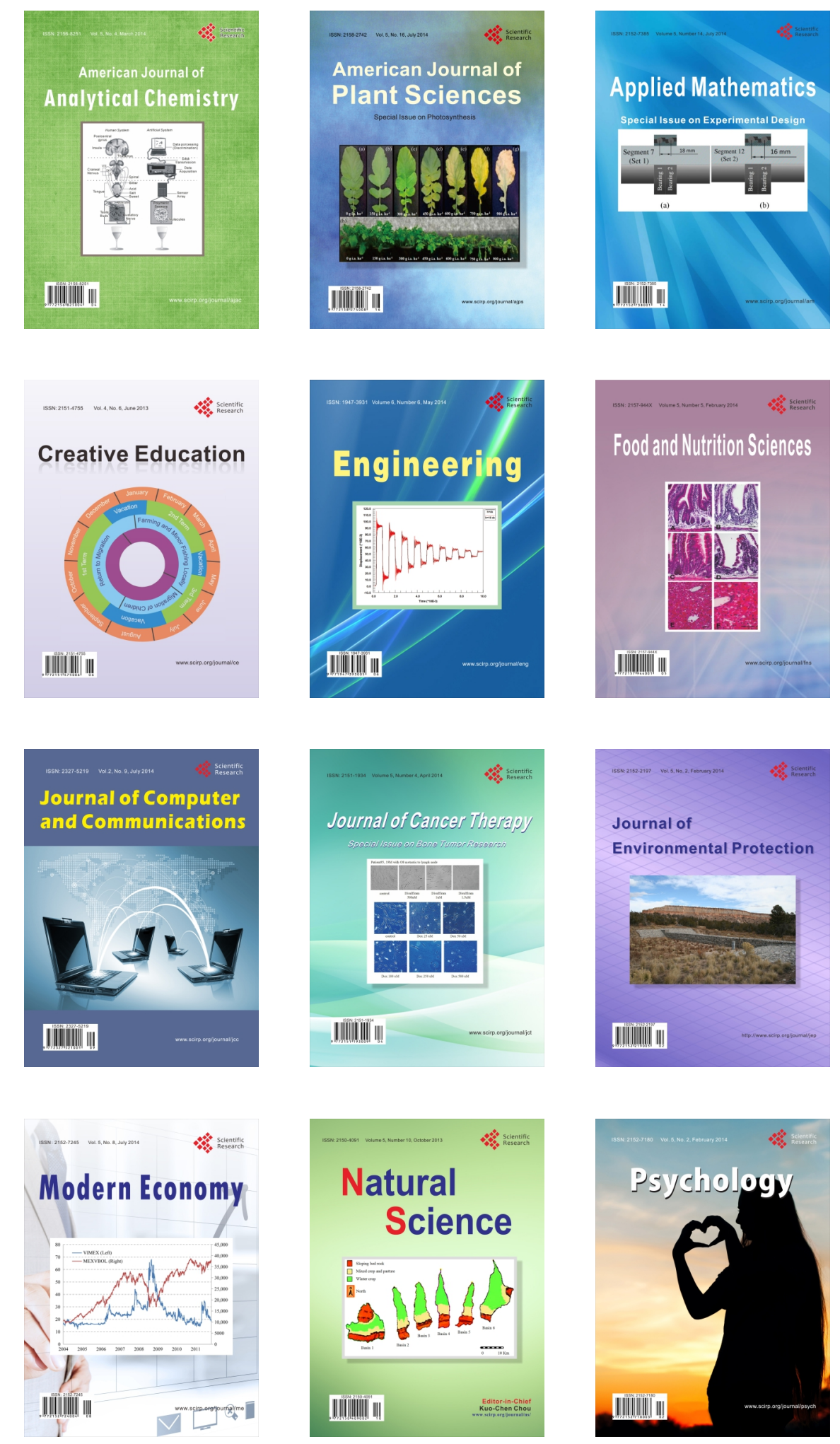